\title{
Increasing Writing Skills In Text Based Short Story (Folklore) Through Audio Visual Media
}

\author{
Yuhartanti, Novia Juita, Yasnur Asri \\ Universitas Negeri padang \\ yuhartanti123@gmail.com
}

\begin{abstract}
This research aimed to improve text-based short story writing skills in folklore through the use of audio-visual media visual in SMA Negeri 1 Batang Anai. The action research was chosen because of how the cycle the increase in text-based short story writing skills in folklore through the use of audio visual media in SMA Negeri 1 Batang Anai. The theory used in this research is, to write short stories, folk tales and audio visual media. This type of research was Classroom Action Research. This research sample class $X$. IIS 4 SMA Negeri 1 Batang Anai. Data collection was carried out by means of tests, the ability of the end use performance test that is writing short stories. Analysis and discussion of the data was done in a descriptive analysis corresponds to the concept of class action research. Based on the results of the research, the findings were: (1) the use of visual media audio can increase the activity of the students. Student activity is increased because the teacher is able to create a learning atmosphere (2) the application of audio visual learning media can improve student learning outcomes. On the application of audio visual use effectively the students who achieve mastery $82.44 \%$. (3) factors affecting the improvement of the learning plan is and engineering teacher teaching using audio-visual media, namely instructional media to suit the learning material and the motivation of the students.
\end{abstract}

Keywords--improved, writing short stories, Folklore Text, Audio-visual Media.

\section{INTRODUCTION}

In Standar Isi (Standard of Content) of Indonesian Language Subjects in SMA/MA elaborated that the scope of Indonesian Language Subjects include language and literary skills component, each of which covers aspects of listening, speaking, reading aspect aspect, and aspects of writing. The fourth aspect of the respective components is integrated in the implementation of the process of learning the language of Indonesia. Tarigan $(1986$, p. 1) stated that the language skills, the over the four components, namely: (1) listening skills (listening skills), (2) speaking skills (speaking skills), (3) intermediate reading (reading skills), and (4) writing skills (writing skills). Rochaeni E $(2015$, p. 2) in Journal of research Education, writing is one of the must have language skills of the students. By writing students can express their ideas or opinions, thoughts, or feelings. In addition, writing can develop intellect and language skills of the students.

Based on an interview conducted on the and September 2016 with several teachers in establishing a discussion forum in Indonesia language teacher MGMP SMA Padang Pariaman, forward several factors learners have difficulty in learning to write. Every time you are asked to complete writing assignments (writing), the students looked confused and lose the idea. Umar S. (2016, p. 282) wrote a short story that student is not the same. Most students are able to write a short story with a good and most of the other students are still not able to write short stories as well. This condition is exacerbated by the low interest of writing students. Writing skills students are still low is characterized by (1) the frequency of writing activities undertaken by students is very low, (2) the quality of the paper very bad students, (3) lack of enthusiasm in following Indonesia in language learning General learning and writing in particular, and (4) lack of creativity belajara student teaching-learning activities at the time of writing.

According to Grigoryan (2017, p. 123) audio - visual and text-based is very useful in raising the awareness of author purpose for writing, for budding writers / new trained to be a writer. Then, in the add by Sundeen $(2017$, p. 30) textvisual text the term is also more accurate term, because children's images functioned more as a substitute for a story is created or a description of a place than artistic expression one might expect from a trained artist. In the process of teaching and learning, the media has a very important function. In general the function of the media is as a supplier of the message. Media teaching can heighten students' learning process in teaching which can in turn heightens the learning outcomes reached. Sudjana (1987, p. 2). Yamac (2016, p. 79) digital storytelling (Audio visual) offers new opportunities for the students to make meaning through model the text, understand the nature of the texts that are diverse and developing 
technology, information and visual. Therefore, the digital story may be used effectively by teachers in low socioeconomic areas to prevent from gap in learning.

According to Nurafifah, d. (2016, p. 2) audio visual media can convey information that has the characteristics of the audio (sound) and visual (picture). The use of audio visual media can be used to study the interaction of children and absorb knowledge through what is seen and heard in. Audio Visual is used as one of the tools to reach a specific audience in a special role for the sake of achieving certain goals. Purwati, P.D. (2012, p. 10) and characteristics specificity/wake up as a medium of instruction, writing short stories covering the criteria development procedure of media, media, media development stage (draft product media, media materials and how to manufacture), as well as how to use the media wake up.

Next study is Sulaiman N (2017, p. 97) in English Language Teaching journal. According to the perceptions of students, having done the research most participants perceived media video as a great tool for the assessment of their authentic life as it provides listening, meaningful, and the real situation is context. That means learning by using the Audiovidual tastes become more alive. Based on class action Research Journal Vol. 16, no. 4, August 2015, the results of research conducted by Setiarini Yuni (2015 h. 61) against the use of audio-visual media, the result is the ability to analyze the elements of a short story. Increased ability to analyze the elements of a short story is evidenced through test results has increased from cycle to cycle I II. Innovation in action II cycle the teacher gives motivation specifically to students in order to be brave and not clumsy anymore when a presentation in front of the class, the teacher doing supervision better so that all students can pay attention to and appreciate the film It aired, the teacher gives guidance and direction so that all students can certainly infer the subject matter.

\section{METHODS}

This research was a Classroom Action Research. Classroom action research was chosen because it has characteristics that correspond to the research objectives, namely to increase the skill of writing short stories from the folklore texts through the application of audio visual media in class X. IIS 4 SMA Negeri 1 Batang Anai. The selection of the design in accordance with the opinion of Kemmis and Mc. Taggart (1992, h. 5). This Class Action Research refers to the opinion of Kemmis and Mc. Taggart (1992, p. 9-14), is the process of action research process is recycled or the cycle starts from the aspect of development planning (planning), action (action) the implementation of the action plan, appropriate observation (observation), reflection (reflection) contemplation towards planning, actions and activities of the success of the results obtained. In accordance with rumusa $\mathrm{n}$ the problem, research purposes, and the results of the initial survey, the author together with the teacher to study language and literature class XI Indonesia as the collaborators made a plan of action that will be performed, to solve the problems encountered in learning to write the short stories (Suharsimi, 2003, p. 34). The steps are done as follows.

a. Conduct discussions with teachers to study language and literature class Indonesia XI to equate the perception about using audio visual media to be used in learning to write a short story based on text folk story in class X. IIS 4 HIGH SCHOOL Country 1 stalk Mounds.

b. Determine the theme and content of learning to write a short story based on text folk story in class X. IIS 4 SMA Negeri 1 Batang Anai.

c. Drafting implementation plans in the form of action learning was implemented.

d. Designing learning scenario writing short text-based folklore in class X. IIS. 4 SMA Negeri 1 Batang Anai.

e. Set the media and learning resources to write a short story based on text folk story in class X. IIS. 4 SMA Negeri 1 Batang Anai.

f. Plan the assessment of the ability to write a short story based on text folk story in class X. IIS 4 SMA Negeri 1 Batang Anai.

g. Assign descriptors and criteria the ability to write a short story based on text folk story in class X. IIS 4 SMA Negeri 1

Batang Anai through the use of audiovisual media.

h. Compile the data recorder tool the learning process in the form of guidelines for observation and format notes field.

In accordance with the characteristics of action research are natural, are implemented in real classroom situations, then this action plan is not a certainty, but rather something is flexible. Course there is little, in accordance with the situation the condition of the school where the research is conducted. This research is planned in three cycles and each cycle is executed two times $(2 \times 45$ minutes $)$. Long time research 1.5 months.

The required data in this study are as follows.

a. Data implementation of learning-related behaviour of teachers and learners, which includes the behavior of the teacher, teacher behavior with the behavior of learners, and learners with learners, as long as the learning process progresses. 
b. The assessment of the ability to write short stories learners do with authentic assessment is to assess the performance of the test sheet of text short stories that have been written.

The Data of this research is the use of audio visual model in learning to write short stories. Research activities were carried out against the teachers when learning process takes place. Data obtained from the subject, i.e. teachers and learners class x. IIS 4 SMA Negeri 1 Batang Anai. Data analysis the researchers do approximate described with words or phrases to derive the conclusion. The steps are as follows, (1) examines all data that has been collected, (2) the reduction of data which involves pengkatagorian and classification, (3) conclude and verify.

Data analysis is performed against the data that has been collected either through observation, recording, as well as documentation. Review of the activities carried out since the start of the overall data were collected and after all of the data collected. After the data is collected, the data reduction includes the designation and classification of data. Since the data collected are very much then to make conclusions that data needs to be simplified. The data has been classified are then displayed according to type in accordance with the research issues. Exposure data is done by displaying information systematically so as to allow researchers can draw conclusions as easily. The data presented in the form of a narrative.

The withdrawal of the conclusions of the data retrieval process is the essence of the cereal research data an increased ability to write short stories through the application of audio visual models. Conclusion the data is done by appealing to the data recorded in early learning, meeting one, one cycle with data taken when action and end action. Conclusion the data stated in the form of qualitative improvement of the ability to write short stories from the folklore between text before and after the action. The withdrawal of the conclusion done by interpreting the data presented. Interpret and conclude research data is determined by the criteria of success of research on qualifications either (B). Abdurrahman and Ellya R. (2003, p. 223) the qualification criteria in effect on aspects of the implementation of the study include the behaviour of learners and teachers in the learning process as well as learning outcomes. The results of the analysis of the learning at each learning wrote a memoir through the application of the criteria of success of learning refers to learning outcomes in the form of authentic assessment (scoring rubric) that reached the learners on each cycle.

\section{Increase in the learning process}

\section{FINDING AND DISCUSSION}

Audio-visual medium learning can improve the quality of the learning process. The learning process is said to be successful if the majority of students are physically active and mentally in the learning activities. Muslikah, (2010, p. 27) explained that the process of learning which is said to be successful if positive behavior change, either in whole or in part on students. A positive attitude that is applied in the form of learning by actively and diligently. Teachers as does not turn a blind eye to the development of students by following the instruction. Teachers have to give appreciation to students who have high loyalty of rebellion have in learning and achievement. Improvement of the learning process of the results of the activity of the teacher and student learning activities at each cycle. The results of the activity of the teachers and learning activities of students seen from observations and notes field. Improvement of the process of learning using learning audiovisual media are described as follows.

\section{The activity of the teacher's Teaching}

Based on the results of the findings on the cycles I and II, an increase in the activity of the teachers can be seen when compared to prasiklus. At the first meeting, the teacher still looks stiff to apply a media audio-visual learning. It happened because the media audio-visual learning is a new thing for teachers to implement in its class. The application of learning in class steps not performed optimally so that affects the learning process. At the next meeting, teachers can already apply the audio-visual learning properly. Teachers can already carry out learning in accordance with the step-bystep audio-visual learning. Audio-visual Learning can help teachers in achieving the objectives of learning Activity writing teachers greet and caring teacher to students on early learning activities make learning pleasurable atmosphere. The attention given the teacher to make students feel honored and happy making students motivated to learn. The atmosphere of the class made the teacher becomes more a passion for teaching.

On a core activity, the teacher guides the students to introduce media activities. Teacher uses media and the benefits of the media in the process of learning, teachers continue to supervise and guide students. This makes the students grew comfortable and happy as it can help them to master the material they are discussed. Teachers always give students motivation not to hesitate to ask questions and opinions so that the confidence of students to actively growing. At the end of learning, teachers invite students together for a summary of the material that has been studied so that students feel closer and feeling appreciated by teachers. Teachers also provide exercises to students in the form of a quiz so students getting excited and pleased. If it is been fun learning, and eager sure learning outcomes can be achieved to the maximum. 


\section{Student Learning activities}

Learning by using audio-visual learning recently applied to the grade X SMAN 1 stalk Termite. Some students initially each awkward, passive, not daring to ask and less open about learning. By applying with Audio-Visual Learning, can affect the psychological elements and more students become active. On the learning process, it is clear that most students are motivated to follow learning, learning so much fun using the media, students dare to ask their friends or teachers, dare to answer the question a friend or teacher, and dare to explain his opinion before the friends of friends. The questions hurled at students, become a problem along to give the answer. Questions from students will be taken by the teacher and other students. The questions students will encourage students who become Active. And none of the students were shy. Students are together contributing as well as in the activities of audio-visual learning, as they undertook to see how the video is displayed. Students are also asked to explain his knowledge before his peers, either orally. Then through this learning can improve the systems that stutter will media and socialization along.

There are several activities by students at each meeting. Student activities in this regard, namely: 1) pay attention to penjelasan teachers, 2) engage students in the use of media, 3) download the question, 4) express an opinion, 5) active task, and 6) are happy and brave. The overall increase is at each meeting as well as in each cycle. This is due to the already created an atmosphere of active learning, students become agile, fun, vibrant and meaningful. The understanding of students against certain material can be developed better. The learning that takes place the students are willing to customize the task and responsibility of the task given by the teacher. Student is able to encourage the other to contribute to the presentation of teachers and respect the opinions of others. In addition, students can team up with a friend and asked the teachers so that the task can be completed quickly.

\section{An increase in the Student Learning Outcomes}

Assessment of the results of the study were shown to know and improve achievement of competence. Learning outcomes assessment instrument is used as a tool to know the shortcomings which belonged to each student. These deficiencies must be immediately followed by the repair process against flaws in the aspect of the results of the study are owned person. Then, as per previous discussion that audio-visual media very form students understand learning presented by the teacher. Every individual has the responsibility to understand the work. Thus, the learning that has been done can improve individual skills in solving problems. In addition, it also increases the commitment to succeed, can eliminate prejudice against bad peers. Knowing the development of student learning outcomes in this study performed with the test, test performance,through organising the evaluation at the end of each cycle.

On the results of this research, learning students in cycle I of $60.89 \%$ and cycle II of $82.44 \%$. The learning outcomes of students of precycle, the cycle of I, and the cycle of II continue to experience increased until it reaches the value of KKM. differ on student learning outcomes on precycle and the cycle I, there are many students who do not meet the criteria that have been set. This happens because the students are still not accustomed to learning with the use of audiovisual. On cycle II, persentage final student learning criterion has already escalate and meet the criteria that have been set. This data states that from the stage of pre-productioncycles, cycles I and II, the attitude of seriousness increasing student learning. This means students have felt the benefits of a good learning situation, because the situation provides an opportunity to the students to understand the subject matter together and be a learning experience.

\section{Factors affecting the improvement of the learning process}

Observationally, notes field, and reflection, can be unknown factors affecting the improvement of the learning process. Improvement of the process of learning is influenced by two factors, namely a learning plan that is used and the techniques of teaching or teacher. Factors of change in the learning plan learning cycles I and II is very influential on the improvement of the learning process. In cycle I, the teacher explains the steps of learning to use media detailed not audio so students feel confusion. Teachers are also not fully learning steps. Exercise in the form of answering questions in the classroom. Some things can interfere with the learning process in the classroom such as, interfere with peers.

Factors engineering/the way teachers teach also affects the improvement of the learning process. In cycle I, students are less motivated to learn, sometimes annoying friend. It hasn't been fullest because teachers motivate students at the time of teaching. Teachers also have yet to manage a classroom to the maximum. Overcome it, teachers should have its own engineering so that some of it does not reoccur. Upon reflection, teachers continue to motivate students to learn with praise and applause. Teachers also manages its own technique class, capable of controlling the activity of the students on the positive. By doing so, the learning process is going well.

Compared with the results of the research Martalena the year 2015 in class VIII B5 MTs Darul Hikmah Soweto, the success of the learning process in the classroom that successfully on cycle II. It indentification that the success of an 
effective research appeared in cycle II. It happened because in this study, teachers have already experienced with the use of audio-visual media is applied and the conditions of the class, but not class now but with the previous class.

\section{Factors affecting the increase of learning outcomes}

Observationally, notes field, and reflection, can be unknown factors affecting the improvement of the learning outcomes. Improvement of the learning outcomes are influenced by two factors, namely the appropriate learning media with material that was studied and learning motivation of students. The factors of learning methods that comply with the material and learning motivation of students learning affect the results obtained. In the process of learning, students have to feel happy and comfortable. Students who feel happy and comfortable at the time learned to motivate students to learn. Compared with the results of the research Martalena the year 2015 in class VIII B5 MTs Darul Hikmah Soweto, the percentage of ketuntasan are classical, i.e. $85 \%$, achieved on activities cycle II. While, in this study, the percentage of ketuntasan in classical amounted to $82 \%$. This indicates that the ability of teachers in teaching and training given to students belong to the same category.

\section{CONCLUSION}

Based on the results of research and can be summed up as follows.

1. The use of visual media-audio can increase the activity of the students. Student activity is increased because the teacher is able to create an atmosphere of learning that the conduct so that can give rise to a positive attitude and self-confidence of students. At the time of learning, teachers have facilitated a series of activities that give the space for the emergence of student activity.

2. Implementation of the medium of instruction, audio-visual can improve student learning outcomes in writing short stories. Jumlah students who reach on two cycles is performed according to KKM set with achievement that is $75 \%$. On the application of audio-visual with which effectively discharging students achieve $82.44 \%$.

3. Factors affecting the improvement of the learning to write a short story with the use of audio-visual media is a plan of learning and teacher teaching techniques. Whereas, the factors affecting the increase of yield increase in learning to write prose short story by using the audio-visual media, namely instructional media to suit the learning material and the motivation of the students.

\section{References}

Abdurahman \& E. Ratna. (2003). Evaluasi pengajaran bahasa dan sastra Indonesia. Padang: FBSS UNP.

Arikunto, S. (2003). A research procedure approach to practice. Jakarta: Rineka Cipta

Grigoryan, A. (2017). Feedback 2.0 in online writing instruction: Combining audio - visual and text-based commentary to enhance student revision and writing competency. International Journal. J Comput High Educ. Springer Science + Business Media, LLC is 2017.

Kemmis \& Mc.Taggart. (1992). Classroom action research. Yogyakarta: Pustaka Pelajar.

Mustika. (2014). Innovative learning in the media. Bandung: Remaja Rosdakarya.

Nurafifah, D. (2016). Audio Visual Media And The Media Picture Cards Against The Ability Of Brushing My Teeth In Pre-school Children. The National Journal. Professor Prodi D3 Midwifery STIKes Muhammadiyah Lamongan. Surya, 2 (8), August, 2016.

Purwati, P. D. (2012). Multifiksi Wake Up Media Development To Increase The Competence Of Junior High Students Write A Short Story. The National Journal. Journal of Elementary Education 1 (1) (2012).

Rochaeni, E. (2016). The increase in short-story writing skills using Media Planned Humor KakaoTalk. The Journal Circumference Widyaiswara. 2 (2), Apr - Jun 2015, p. 01 - 15. ISSN: 2355-4118.

Setiarini , Y. (2015). The efforts of improving the ability to analyze the elements Of a short story in the Audiovisual Media. Didaktikum: A Journal Of Research Action Class. ISSN 2087-3557.

Sudjana, N. (1987). The basics of teaching and learning. Bandung: Algensindo.

Sulaiman n. et al. (2017) Students ' Perceptions on Using Different Listening Assessment Methods: Audio-Only and Video Media. English Language Teaching, 10 (8); 2017

Tarigan, H. G. (1986). Literary Appreciation guidance volume 1 short story and Novel. Bandung: Angkasa.

Umar, S. (2017). Short story Writing skills improvement with The Master Copy of the Strategy through the Audiovisual Media in the Grade 2 Land JUNIOR IXa of Tolitoli. The National Journal, the journal of creative Online Tadulako 4 (6) ISSN 2354-614X.

Yamac, A. (2016). The Effect of Digital Storytelling in Improving the Third Graders Writing Skills. International Electronic Journal of Elementary Education, 9 (1), September 2016, p.59-86. 